\title{
PRODUCT DESIGN AS A CREATIVE METHODOLOGY AMONG SCIENTIFIC- TECHNOLOGICAL AND ARTISTIC EDUCATION
}

\author{
Joseba K. Azcaray Fernández¹, Manuel Martínez Torán²,Marcelo Leslabay \\ Martínez ${ }^{3}$, Chele Esteve Sendra ${ }^{4}$ \\ ${ }^{1}$ Department of Engineering Design, Universitàt Politècnica de València, Spain \\ ${ }^{2}$ Drawing Departament, FabLab Valencia, Universitàt Politècnica de València,Spain \\ ${ }^{3}$ Departament of Industrial Technologies, Universidad Deusto, Bilbao,Spain \\ ${ }^{4}$ Drawing Departament, ETSID-UPV,Universitàt Politècnica de València, Spain
}

\begin{abstract}
The rise of 21st century technologies means the integration of art term as creative expression into scientific and technology competences. It breaks a new ground in the field of knowledge, leading to debate new and updated learning methodologies for their implementation in the education system. It is carried out a review on STEAM educational tendency and a focused-on design Project-Based Learning (PBL), as a bond between artistic education and science and technological education. The aim of this work is the analysis of renewed methodologies, in order to carry out a qualitative assessment through observation and, this way, outline directions for future research.
\end{abstract}

\section{KEYWORDS}

New technologies, Product Design, 3D Print,PBL,Education, Curriculum

\section{INTRODUCTION}

The entry to the 21st century of new technologies based on the new information and communication technologies (ICT), has caused changes in education, creating new approaches about knowledge acquisition and the way learning is generated. This new theoretical framework, raises again the problem of the historical distance between art and science, towards a development of current methodologies for the integration of every ability in a sole multidisciplinary subject.

At this time, it is a fact that teachers and students face with new education challenges, pulling away traditional teaching methods. Maseda and Ruiz [1] stated that 'new technologies promote content working in an innovative way, they make easier self-learning and, at the same time, they stimulate activity and creative thinking, $[\ldots]$ facilitating the knowledge of more people, those which experiences can be shared with'.

From a general point of view, every human made technology in the form of product is the result of a project-based engineering process. Miaoulis [2] said that 'the model for education must change and use engineering directed towards a more entertaining and contemporary world-related study of science'. 
International Journal of Education (IJE) Vol.6, No.1/2, June 2018

But this does not mean that a science and technology-based learning avoids the artistic component. According to Cilleruelo\&Zubiaga [3] once the product is carried out, this possesses certain characteristics that indicate key skills to success.

These abilities open new doors to the artistic education understood as a bond for the development of a curriculum where every discipline is integrated [3].

\section{THEORICAL FRAMEWORK}

In light of this situation, it emerges the necessity of creating new generations able to make up an education based on Science, Technology, Engineering and Mathematics (STEM), in order to satisfy the continuous technological changes [4].

This paradigm contemplates technology from a science-based approach. According to Yakman [5], to generate knowledge, besides integrating above mentioned competences into education, it is also necessary to place in arts-based skills, producing this way a bond between the artistic and the STEM.

Many researches reveal that the arts considered as 'beaux arts' influence in a very positive way the development and education of the child.

Following Yakman's theories, several authors, define the concept of art in a more concrete way, placing it within an interdisciplinary process based on STEM [6], and cataloguing it as the creative component that is missing in a scientific and technology competence-based project [7].

Ruiz, Zapatera and Nicolás [4] said that '[...] the inclusion of art is something that is naturally occurring at present, since the STEM learning practices' implementation turns to art in order to supply the lack of creativity that the projects possess'.

This concept can be reflected on Horizon report 2015 [8], where it is described and identified on an international scale which technologies and tendencies in education will be a turning point within the next five years.

In a short-term implementation it can be observed the incorporation of the ' $\mathrm{A}$ ' of art to the STEAM education tendency. At the same time, the usage of new technologies as a tool increases in all the fields that form the education curricula.

The integration of artistic concepts within science and technology competencies opens up the door for a new interdisciplinary paradigm. Putting into education framework context, the implementation of a STEAM learning has been linked to the use of new technologies, where students are characterized by being able to understand what they do, reflect about their work, set goals, and make a self-assessment in order to learn and generate knowledge.

Ocaña et al. [9] describes an educational context in which new technologies are applied through the STEM paradigm, by using the 'Project-Building' method. It establishes a kind of learning where students have to solve problems through the development of a project, supported by methods proper to engineering. The purpose is to turn it into a product, integrating multidisciplinary knowledge taken from science and technology, favoring creative thinking.

The use of this knowledge in a multidisciplinary way is carried out through a PBL. Problem solving is suggested from taking new concepts, which integrate the most number of knowledge fields [10]. This teaching methodology has been the one selected by numerous educational 
International Journal of Education (IJE) Vol.6, No.1/2, June 2018

institutions for the inclusion of new tools and technological resources that are in constant evolution. This way new scenes commence and lay bare the necessity of a new teaching-learning model, where students turn into the principal of their self-learning [11].

PBL methodology is based on constructivist learning. According to Papert [12], constructivism within education is understood as an educational framework focused on the individual, where knowledge is generated in a more optimal way, and turning the students into the principal of their own learning process.

Generally, the implementation of new technologies comes together with the use of science and technology competencies, but applied under a PBL method for the design of a product, it requires the development of new skills typical of artistic education and creativity. Ocaña et al. [9] say that it is necessary to stimulate creative thinking to develop and favor the construction of new knowledge.

According to Bonet et al. [13], the development of creative skills qualifies students to find solutions to problems. This, fomented under a project-based and constructivist approach [7], allows students to create ideas, do research and build them up [14].

\section{CASE STUdY}

Txikitech is founded in 2015 to develop the project "Engineering for children". It is located in Bilbao, Spain. It is formed as a research and development centre to integrate new technologies into the educational curriculum. The need to incorporate a supplementary technological training based on the regulated education with a high percentage of students was identified. The project was focused on various national and international investigations and studies with educational, technological and engineering nature.

In this investigation it is studied and applied a methodological development that integrates creativity in science and technology and the use of new tools. The aim is to make a qualitative evaluation through analysis in order to obtain results. Thanks to those, new objectives and shortterm investigation lines are considered to be investigated, analyzed, experimented and applied afterwards.

The results of this case study will be obtained according to a qualitative evaluation where the student will have to pass all the objectives through the abilities for a formal education that are underlined in the 2nd article of the Royal Decree 1105/2014 issued on December 26th, p. 7 of Spanish Education:

- Linguistic Communication.

- Mathematical competence and basic science and technology competences.

- Digital competence.

- Learning to learn.

- Social and civic competence.

- Sense of leadership and entrepreneurship.

- Conscience and cultural expressions. 


\subsection{Methodological design}

The integration of creativity as a link between artistic education and science and technology to develop an interdisciplinary educational model is proposed.

The educational paradigm STEAM, integrated in the curriculum and competences of educational institutions in various countries, is set as the starting point. The existing connection between science, technology and mathematics can be understood in in a combined [15] and supplementary way. Its combination, makes an interdisciplinary unit instead of being used as independent competences.

Engineering is focused as the process that needs to be followed to learn the previous units. From a general point of view, engineering is based on the development of a project for the construction of a product where science and technology concepts are integrated.

In this case study it is considered that in an education oriented to children with a project-based learning, the student will put into practice educational units such as mathematics, technology, drawing, electronics, programming, electricity, mechanics, etc., becoming aa multidisciplinary subject. This paradigm is supported by various researchers [16], who contend that accomplishing this multidisciplinary process can be done from a PBL based on design and a constructivist learning [17].

These methods indicate that students do not acquire knowledge through a conceptual study, but that it comes with active experiences, getting to be the leaders of their own learning. The student will be prepared to conceive, think, imagine, experiment, decide, investigate, develop, innovate and invent in a creative process.

To integrate artistic education in a science and technology project, creativity is framed inside a product design process based in engineering. Art understood as design [18] owns innovation characteristics and according to the Rhode Island School of Design quoted by Martínez [19] and Ruiz [4], this has to appear in every scientific-technological process making it a mandatory subject for learning.

In Figure 1, it is described the methodological development for the launch of this methodological process in case studies. It is observed that to generate a science and technology learning under the STEAM multidisciplinary approach, art takes part understood as design, and transforms that way into the creative way to link artistic education and engineering.

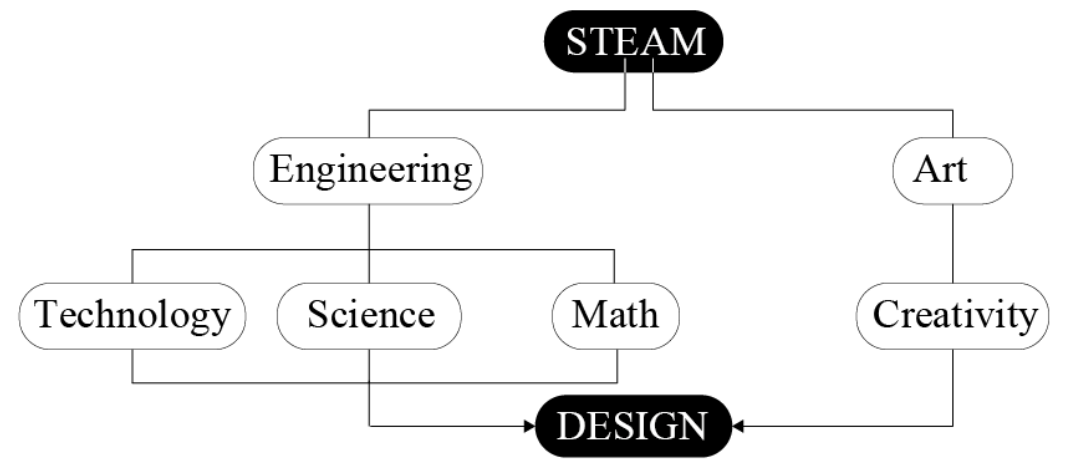

Figure 1. The Design between artistic education and scientific - technological education 
International Journal of Education (IJE) Vol.6, No.1/2, June 2018

\subsection{Description of case studies. Methodological intervention}

The application of this methodology is developed in the school Txikitech with involvement of 24 children aged between 14 and 16 during the school year 2017.

To develop the object of study we define the project inside the general objectives established inside the legal basic education curriculum known in Spain as "EducaciónSecundariaObligatoria (ESO)", published in the "BoletínOficial del País Vasco (BOVP)" on January 15th 2016, Friday (pp. 237-279), in subject corresponding to "technology".

The case study consists of the design of a physical object starting with the idea until its manufacturing and presentation following a PBL based in design (Figure 2).

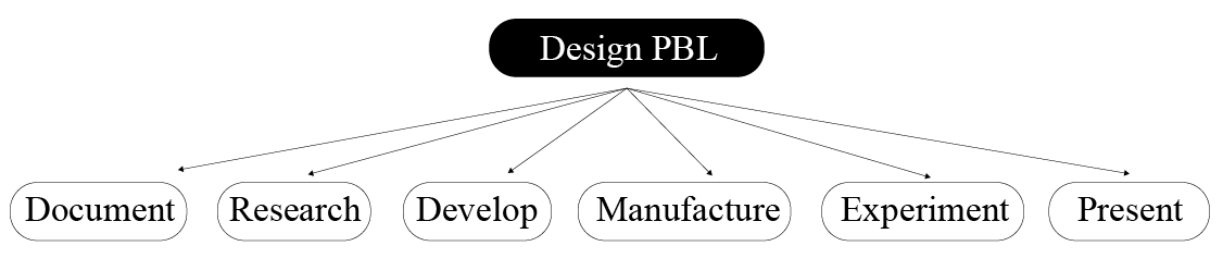

Figure 2. PBL based in design

For its development different educational units such as mathematics, computer science, social science and technical drawing have to be used. For the manufacturing a 3D printer as tool and resources based in new technologies are used.

It is expected that through a process of product design, the student will use new technologies and therefore develop his creative and technical abilities together and applying different areas of knowledge.

Table 1 shows the number of sessions and the duration of each of the stages that have been necessary for the realization of the case study:

Table 1. Duration of the case study

\begin{tabular}{|c|c|c|c|}
\cline { 2 - 4 } \multicolumn{1}{c|}{} & Session & Hours & Total Hours \\
\hline Document & 1 & 2 & 2 \\
\hline Research & 2 & 2 & 4 \\
\hline Develop & 3 & 2 & 6 \\
\hline Manufacture & 2 & 2 & 4 \\
\hline Experiment & 4 & 2 & 8 \\
\hline Present & 1 & 2 & 2 \\
\hline
\end{tabular}

Figure 3 shows the briefing of the exercise proposed by the students: 


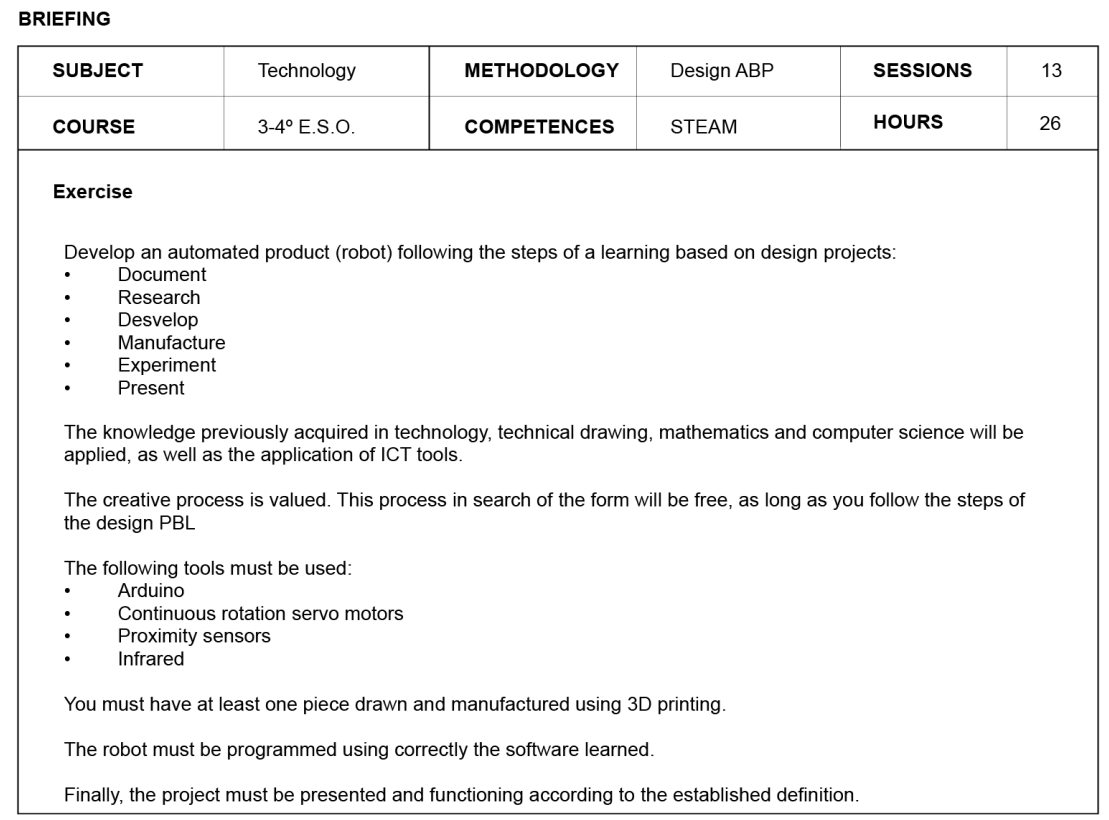

Figure 3. PBL stages based on design

A description of the development of each of the stages carried out by the students is made:

Collection of data: the teacher generates all the information about a topic and provides the student with the necessary documents, in order the acquire knowledge. This new information is managed using new ICT tools, transforming it into a teacher-student communication channel. Students collect data from other projects with similar characteristics, so they supply those students with new approaches and alternative proposals to face the ongoing project.

Thinking-out: students gather in groups to explain their own designs. They analyze and develop new proposals, encouraging creativity while searching the creation of a product and the definition of the activity they must present. Group work for the generation of ideas is fomented (Toledo, Garber, \& Madeira, 2017).

Developing: students put into practice knowledge acquired from other educational competencies. They start to develop those previously proposed ideas to build the project. They also show sketching and 3D painting abilities and the usage and managing of ICT, computers and different necessary software for its development.

Manufacturing: proposals devised and developed in previous stages are now worked out. New digital fabrication tools are used for this purpose. Students can live in real time the prototyping process. The use of these tools provokes motivation for learning and the comprehension of the concepts in a more experimental way (Álamo García, 2017). In Figure 4 it observes the fabrication, through 3D printing, of a piece that is part of the conceived robot. 
International Journal of Education (IJE) Vol.6, No.1/2, June 2018

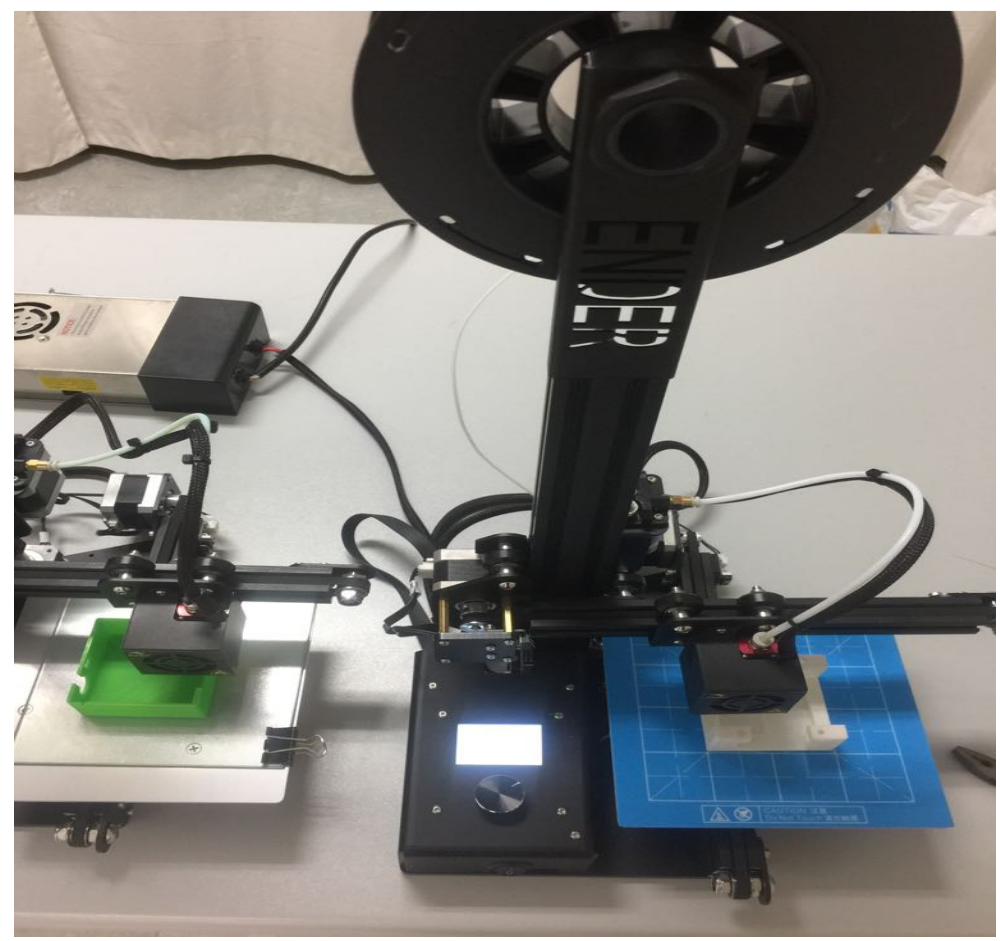

Figure 4. Production stage using printing

Experimenting: students mount and assemble the product. They observe and analyse possible mistakes through experimentation and, if it any such error exists, they must go back to the development process. Meanwhile, students experiment with the functioning of the robot using Arduino's programming processor, until achieving the result defined at the thinking-out stage. In Figure 5 it can observe the prototype worked out by using 3D printing and the different pieces that form it before the assembly process.

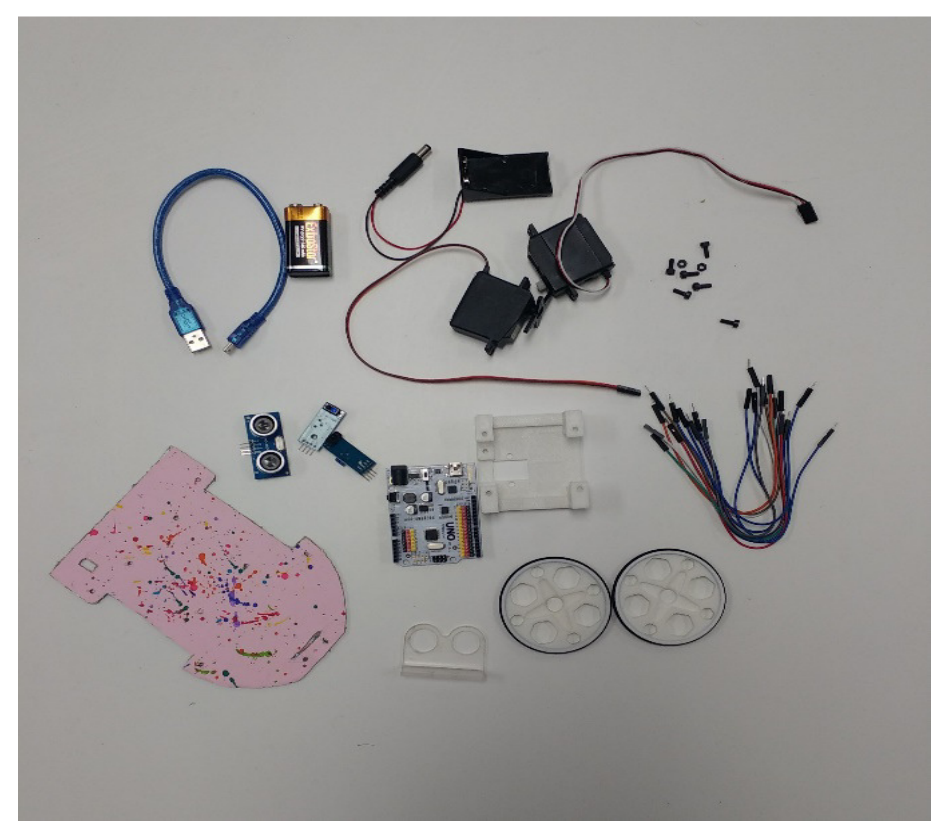

Figure 5. PBL stages based on design 
Presentation: when the project is finished, this is presented in front of the rest of participants, explaining them the processes and the experience carried out. In Figure 6 it observes the operating of a robot following the black line.

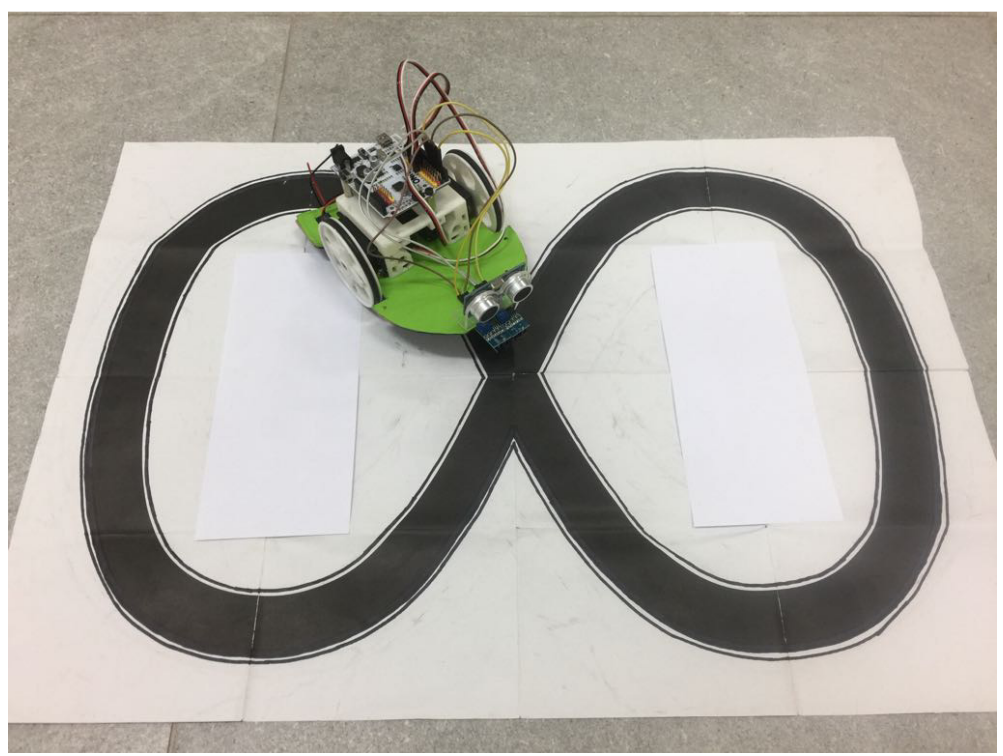

Figure 6. Presentation of the final product

\section{RESULTS}

Through the observation and experimentation carried out during the previous case, a qualitative assessment is made. Results are achieved according to basic competencies that the learner must pass, based on the 2nd Article of the Royal Decree 1105/2014 on the 26th of December within the Spanish Education:

- Linguistic competence: the PBL design-based learning supposes a language acquisition characterized by cooperation and group work, encouraging this way participation and communication among co-workers. Furthermore, the integration of new technological tools and software for its proper operation suggests the inclusion of new terminology which must be learnt

- Mathematical competences and basic competences in science and technology: the development of the project is worked out under the STEAM educational tendency. To face appearing problems, students apply previously acquired knowledge in the subjects proper of mathematical, science and technology basic competences. That is how it turns into a multidisciplinary activity within de educational curriculum. The incursion of creativity inside a technological project generates synergies among different basic competencies, leading to new activities and experiences.

- Digital competence: the use of new technological tools applied to the development of a project generates a continuous learning of competencies were ICTs are applied. New graphic and software settings are used, opening alternatives for new technological products that, besides in classroom, they could be used in daily life. An example of that could be new digital making software and 3D printing production. 
- Learning to learn competence: the use of new technologies in the classroom supposes a motivation for the student, leading this way to new learning opportunities. The development under a PBL has strengthen the creativity focused on problem solving, helping the student to find problems setting the basis on multiple solutions.

- Social and civic competence: during diverse stages of project development, communicative ability arises among the individuals that are part of the teamwork. This is necessary to the generation of ideas and the searching of solutions to problems. Sense and critical ability towards current society's problems are developed.

- Cultural awareness and expression: while working out a project related to a current society's product, it demands the application of knowledge with a critical sense. This supposes an active search of data that allows the student to fulfil a learning on principles and knowledge further than competencies acquired in the classroom.

- Sense of initiative and entrepreneurship: the usage of mathematics, informatics, science and technology from an experimental point of view and based on design PBL, implies the possibility for the student to turn ideas into objects. This ability of bringing life to ideas through new technologies promotes creativity, allowing that way to experiment it during almost all the product designing stage. This experiencing facilitates the attitude of enthusiasm and motivation towards learning. According to Azcaray et al. [20], the integration of ICT like the 3D printer as an experimentation and manufacturing tool, and new software for the development of a design based PBL methodology, provokes cognitive changes and new behavior in the student. This ability of initiative and entrepreneurship, from a knowledge construction point of view, allows student to activate a more autonomous learning, questioning the 'I used to do it that way and now I do it this way'.

\section{CONCLUSIONS}

The practical objective of this case consist on the creation of knowledge within different curricular fields integrated in a disciplinary subject. It is required the development of a new educational methodology based on those previously existent, where new digital fabrication technologies could be integrated into arts and science academic fields.

- It is carried out throughout observation and a qualitative assessment of how students have accomplished different design-based challenges and projects over the sessions. In addition, these serve for the analysis and improvement of current and future research:

- The utilization of digital fabrication in education is presented as the resource and tool to perform a STEAM process within education system.

- Based on a design-focused PBL, it allows students explore ways of learning supplementary to the traditional education. Product design produces motivation towards active learning, where problem solving develops cognitive abilities and stimulates creative and critical thinking.

- The implementation of a STEAM learning through a project and using new technologies, creates motivation for learning. Students turn to knowledge acquired from different fields and integrate them into the project. Interest about how things are made and what are they used for increases. 
- Creativity in a design-focused process provides students with development and problemsolving skills. Through a methodology based on the principles of constructivism, they are able to select multiple variations for the development of the task. This solution searching produces an increase in self-esteem and self-confidence. That increase strengthens knowledge and the 'how to make' concept.

- Students develop working in group skills and, because of the realisation of the task, they learn solidarity towards their peers.

Product designing under a PBL within a STEAM process enables the student to experiment with concepts which can be applied to real life. This arises the interest for new technological tools and their implementation on new personal projects.

\section{FUTURE RESEARCH}

The rise of new technologies has meant and evolution in the way of integrating science and technology within educational curriculum. Digital fabrication tools have turned into a way of communication between real life products and those made in classrooms.

According to Cilleruelo\&Zubiaga [3] it is perceived that artistic education must search new ways of expression and learning methodologies, created to be useful and accepted within the education framework. In the same way, science and technology have to be experimented further than the traditional and conceptual approach.

Within education framework, a PBL based on design generates the bond to deal with this multidisciplinary paradigm and to be able to take a close look at new educational proposals in order to face the continuous technological changes.

On the basis of this research and within curricular frame, it is developed a didactic unit to tackle a PBL based on design, by using new technologies and digital fabrication.

New work spaces are posed with the goal of developing projects based on new technologies and digital fabrication. FabLab and Maker Space could be taken as reference examples. These are distinguished by developing projects which are related to product design throughout machines capable of producing any other wanted object.

A new teacher model is studied. This must assume new roles for the construction of knowledge from a multidisciplinary approach.

It breaks a new ground in research for the integration of new technologies as a creative learning tool within a STEAM multidisciplinary educational framework.

\section{REFERENCES}

[1] E. Maseda Truchado and J. Ruiz Arriaza, Apliquemos las TIC en el aula de Legua y Literatura y pongamos un mundo maker al alcance de nuestros alumnos, Málaga: UMA Editorial, 2017.

[2] M. "El reto de la alfabetización tecnológica," in Aprender hoy para solucionar el mañana, Barcelona, 2015.

[3] L. Cilleruelo and A. Zubiaga, "Una aproximación a la Educación STEAM. Prácticas educativas en la encrucijada arte, ciencia y tecnología," in Jornadas de Psicodidáctica, 2014. 
International Journal of Education (IJE) Vol.6, No.1/2, June 2018

[4] F. Ruiz Vicente, A. Zapatera Llinares and N. Montes Sánchez, Diseño de proyectos STEAM a partir del curriculum actual de Educación Primaria utilizando Aprendizaje Basado en Problemas, Aprendizaje Cooperativo, Flipped Classroom y Robótica Educativa, Valencia: Universidad CEU Cardenal Herrera, 2017.

[5] G. Yakman, "STEAM education: An overview of creating a model of integrative education," in Research on Technology, Innovation, Design \& Engineering Teaching, Lake City, Utah, 2008.

[6] L. Vasquez Giraldo, Hacia un perfil docente para el desarrollo del pensamiento computacional basado en educación Stem para la Media Técnica en desarrollo de software, Medellín: Tesis de Maestría. Universidad EAFIT, 2014.

[7] D. A. Hernández Londoño and Martínez A., Interfaz de programación visual como herramienta educativa para el desarrollo de competencias en ciencia y tecnología por parte de niños, jóvenes y educadores, Medellín: Universidad Pontificia Bolivariana. Escuela de Ingenierías., 2016.

[8] L. Johnson, S. Adams Becker, V. Estrada and A. Freeman, The NMC Horizon Report: 2015 Higher Education Edition, Austin: New Media Consortium, 2015.

[9] G. Ocaña, "Robótica en el aula,” Consejería de educación de la Junta de Andalucía, Almería, 2012.

[10] L. Rojas, S. Rojas and E. Vargas, "Diseño de un entorno B-learning para la educación en tecnología con enfoque STEAM,” Universidad Distrital Francisco Jose De Caldas, Bogotá, 2017.

[11] E. González and A. del Valle López, El aprendizaje basado en problemas: una propuesta metodológica en educación superio, vol. 18, Narcea Ediciones, 2008.

[12] S. Papert, La máquina de los niños- Replantearse la educación en la era de los ordenadores., Barcelona: Paidós Ibérica S.A., 1995.

[13] Bonet, C. Meier, J. L. Saorín, J. de la Torre and C. Carbonell, "Tecnologías de diseño y fabricación digital de bajo coste para el fomento de la competencia creativa," Arte, Individuo y Sociedad, vol. 29, no. 1, pp. 89-104, 2017.

[14] J. Vega and J. Cañas, “ Curso de robótica en educación secundaria usando constructivismo pedagógico,” in Jornadas de Innovación y TIC Educativas - JITICE’14, 2014.

[15] M. Sanders, "Integrative STEM education: primer.," The Technology Teacher, vol. 68, no. 4, pp. 2026, 2009.

[16] F. Á. Bravo Sánchez and A. Forero Guzmán, "La robótica como recurso para facilitar el aprendizaje y desarrollo de competencias generales,” Educación, pp. 120-136, 2012.

[17] M. Collazos Vargas and L. M. Mesa Velasquez, "Luces y sombras en la formación en robótica: el caso Pygmalion,” Medellín, 2016.

[18] J. J. M. Maeda, Las leyes de la simplicidad: diseño, tecnología, negocios, vida, 2008.

[19] M. Martínez Torán, “¿ Por qué tienen tanta aceptación los espacios maker entre los jóvenes?,” 2016. [Online]. Available: www.investigacionjuventud.org.

[20] J. K. Azcaray, M. Martínez Torán, M. Leslabay Martínez and C. Esteve Sendra, "Product Design \& 3D Printing : Integrating New Technologies into The Curriculam - Case Study," International Journal on Integrating Technology in Education, vol. 6, no. 4, pp. 11-23, 2017. 


\section{AUTHORS}

Joseba Koldobika Azcaray Fernández is a design, manufacturing and Projects engineering $\mathrm{PhD}$ student at the Polytechnic University of Valencia, Spain. He is currently the director and professor of Txikitech school and is investigating an educational program about how to implement new technologies in the educational process through different methodologies. As an industrial designer he excels in new product investigation and tools for education.

Manuel Martínez Torán PhD is a professor and design researcher at UPV and Director of FabLab Valencia. He has participated in two European and 25 R\&D design project as principal researcher (PI). He has published five books, twelve book chapters, fourteen contributions at conferences and has four recognized patents. He has been visiting lecture in Argentina, Mexico, Chile and Colombia. He has seven doctoral thesis read and one live stage of recognized research from Spanish Ministry of Education.

Marcelo Leslabay PhD Doctor of the Polytechnic University of Valencia. For more than 25 years he has been managing his study Leslabay Design, specialised in exhibition curator, design and organization representing Spanish design in several countries. He is currently Project Manager at Deusto FabLab, manager of the Industrial Design Engineering Degree, manager of the Ecodesign Lecture Room and Industrial Design professor at DeustoUniversity, Bilbao, Spain. He has been Editorial Director at Experimenta since 2015, a publishing house specialised in Project, Design and

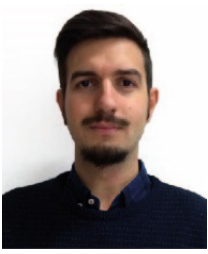
Communication Culture.

Chele Esteve Sendra PhD Senior Lecturer is a professor at ETSID-UPV (School of Design and Engineering) and Head of Industrial Design Master's Degree at Higher Polytechnic School, Universidad de Nebrija (Madrid).She is interested in how everything is connected: people, objects, ideas and cultures. The quality of the connections is the key to success in a society which advocates multiculturalism. Chele's work focuses on the research and development of new products and market trends. She is working with the Museum of Crafts of Valencia (Spain), showing the blurred boundaries and emerging
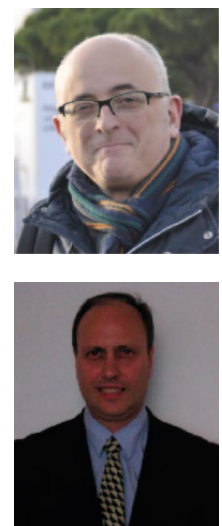

alliances between designers and craftsmen. She shares her work as a professor, designer, as well as a Design\&Art critic and exhibition curator. 